\title{
Perception of Civil Engineering Students Towards the Effectiveness of Virtual Learning Implementation During Covid-19 Pandemic
}

\author{
Arie Wardhono ${ }^{1 *}$ Andang Widjaja ${ }^{1}$ Didiek Purwadi ${ }^{1}$ Bambang Sabariman ${ }^{1}$ Arik \\ Triarso $^{1}$
}

${ }^{1}$ Department of Civil Engineering, Universitas Negeri Surabaya, Surabaya, East Java, Indonesia

*Corresponding author. Email: ariewardhono@unesa.ac.id

\begin{abstract}
The Coronavirus disease 2019 (Covid-19) epidemic is increasingly spreading throughout the world and has been declared a pandemic by world organizations. This compels educational institutions to issue a lockdown policy oncampus activities by emphasizing at online learning (virtual learning) process. This study aims to identify the perception of civil engineering students towards the effectiveness of virtual learning implementation during the Covid-19 pandemic. This is descriptive research involves a questionnaire with a Likert scale technique. The questionnaire was developed by google form application and distributed by email. The subject was 50 civil engineering students who enrolled in basic engineering and structure courses. The results showed that the implementation of virtual learning was not quite effective based on civil engineering student's perception. Despite the students were quite an enthusiasm due to its technical challenge and time flexibility, there are some major problems in virtual learning implementation which are required to be addressed first. These problems are the level of understanding, the social interaction during virtual learning, the internet cost, and internet access and facilities. Therefore, the role of institutions is required so that the virtual learning implementation during the Covid-19 pandemic can be applied as expected.
\end{abstract}

\section{Keywords: Perception, engineering student, effectiveness, virtual learning, Covid-19 pandemic}

\section{INTRODUCTION}

Indonesia has officially declared the Coronavirus disease 2019 (Covid-19) epidemic as a national disaster through the issuance of Presidential Decree (Keppres) No. 12 of 2020. The outbreak of the COVID-19 in all regions of Indonesia has compelled the Ministry of Education and Culture (Kemendikbud) to issue a Letter (SE) Number 4 of 2020 concerning the implementation of educational policies in the emergency period of the spread of Covid-19 which emphasized the process of teaching and learning from home through online learning. Most of the educational institutions in Indonesia, especially universities, have issued a lockdown policy on-campus activities [1,2] with an emphasis on online or distance learning processes in following up on the instruction. All learning activities must be conducted online using electronic learning (e-learning) or virtual learning (vilearning) methods [3]. These activities can be performed using free-online platforms or applications such as zoom, google meet, WhatsApp, skype, facetime, etc.

At first, the concept of virtual learning was developed not to replace conventional or face-to-face learning. Combining face-to-face learning with the virtual learning concept will enable an increase in learning quality, as well as an improvement in the effectiveness and efficiency of education. Virtual learning is developed to support face-toface learning and can be applied as the only learning process in distance education or combined with direct or face-to-face learning in the class [4].

However, the implementation of virtual learning has not yet an obligation in learning activities. The use of virtual learning is still considered as a complement to conventional or face-to-face learning methods. Also, the direct interaction between lecturers and students will be reduced, as well as the social interaction amongst the students itself $[5,6]$. Further, in normal conditions where all students can perform the learning activities on their 
educational institutions or universities, internet access and cost are not a problem to the implementation of virtual learning because it has been facilitated by institutions. The problem is when the institutions issued a lockdown policy on-campus activities due to the handling of the Covid-19 pandemic. This means that all teaching and learning activities are carried out online or remotely from their respective residence, where the internet access facilities and costs must be borne by each individual, both lecturers, and students. This will significantly affect the effectiveness of the virtual learning process, as well as student learning motivation where they must provide internet access and costs in private.

This paper aims to identify the perception of civil engineering students, which is enrolled in basic engineering and structure courses, towards the effectiveness of virtual learning implementation during the Covid-19 pandemic in terms of learning motivation, level of understanding, learning interaction, and learning problem encountered. The results of this study are expected to be used to improve the teaching and learning process with virtual learning methods, notably in basic engineering and structure subject in the civil engineering discipline.

\section{METHODS}

\subsection{Population and Samples}

This is descriptive research. It involves a questionnaire used to collect data. The research populations were undergraduate students pursuing a bachelor's degree in Civil Engineering Department, Universitas Negeri Surabaya. The samples used in this research were 50 undergraduate students who enrolled in basic engineering (material engineering) and structure (steel structure) courses. These courses were chosen due to the implementation of the direct learning methods during the learning process so far.

\subsection{Research Instrument}

The instrument of this research was developed to identify the perception of civil engineering students towards the effectiveness of virtual learning implementation during the Covid-19 pandemic. The research variables were categorized into four groups, i.e. motivation, level of understanding, learning interaction, and learning problems as shown in Table 1.
Table 1. Research instruments

\begin{tabular}{|c|l|l|}
\hline No & $\begin{array}{l}\text { Perception of } \\
\text { virtual } \\
\text { learning }\end{array}$ & \multicolumn{1}{|c|}{ Research Variables } \\
\hline 1 & Motivation & $\begin{array}{l}\text { Pleasant, enthusiasm, and } \\
\text { challenges }\end{array}$ \\
\hline 2 & $\begin{array}{l}\text { Level of } \\
\text { understanding }\end{array}$ & $\begin{array}{l}\text { Increased understanding, easy } \\
\text { to understand, and course } \\
\text { exercises }\end{array}$ \\
\hline 3 & $\begin{array}{l}\text { Learning } \\
\text { interaction }\end{array}$ & $\begin{array}{l}\text { Interaction student to the } \\
\text { lecturers, interaction student to } \\
\text { student, and miscommunication }\end{array}$ \\
\hline 4 & $\begin{array}{l}\text { Learning } \\
\text { problems }\end{array}$ & $\begin{array}{l}\text { Cost, time flexibility, internet } \\
\text { access, and infrastructure }\end{array}$ \\
\hline
\end{tabular}

The instrument used 5-Likert Scale items to determine the perception of the effectiveness of virtual learning implementation [7]. The scale was determined based on $1=$ disagree, $2=$ quite disagree, $3=$ quite agree, $4=$ agree, and $5=$ strongly agree.

\subsection{Data Collections}

The research primary data of this research was collected through a questionnaire that was developed by google form application [8]. The questionnaire was divided into five sections consisting of 1) respondent profile, 2) motivation, 3) level of understanding, 4) learning interaction, 5) learning problems.

\section{RESULTS AND DISCUSSION}

The results of this research are discussed in six sections. The first and second sections consist of the respondent profiles and motivation. The third and fourth sections deal with perception towards the level of understanding and learning interaction during the virtual learning process, respectively. While the last section discussed the learning problems encountered during the implementation of virtual learning.

\subsection{Profile of Respondents}

The profile of the respondents is $29(58 \%)$ male and 22 $(42 \%)$ female undergraduate students with the age between 18-20 years old (average age of 19.4 years old). The profile of respondents towards the virtual learning implementation during the Covid-19 pandemic are shown in Table 2.

Table 2. Profile of respondents

\begin{tabular}{|c|c|c|}
\hline Characteristics & Frequency & $\begin{array}{c}\text { Percentage } \\
(\%)\end{array}$ \\
\hline
\end{tabular}




\begin{tabular}{|c|c|c|}
\hline \multicolumn{3}{|c|}{$\begin{array}{l}\text { The gadget used by } \\
\text { respondents }\end{array}$} \\
\hline Laptop & 44 & 51 \\
\hline Mobile phone & 40 & 47 \\
\hline$P C$ & 1 & 1 \\
\hline Others & 1 & 1 \\
\hline \multicolumn{3}{|c|}{$\begin{array}{l}\text { Location during the virtual learning } \\
\text { activity }\end{array}$} \\
\hline House & 47 & 81 \\
\hline Internet cafe & 5 & 9 \\
\hline Friend's house & 6 & 10 \\
\hline \multicolumn{3}{|c|}{$\begin{array}{l}\text { Online platform application is known by students } \\
\text { for virtual learning }\end{array}$} \\
\hline Zoom & 49 & 38 \\
\hline Google meet & 41 & 32 \\
\hline Whatsapp & 39 & 30 \\
\hline Skype, Facetime & 0 & 0 \\
\hline
\end{tabular}

According to Tabel 2, laptops $(51 \%)$ are the most favorite gadget used by respondents during a virtual learning activity, followed by mobile phones (47\%). This is due to the gadget flexibility that is easy to carry and used anywhere. Further, in terms of location, house (81\%) is the most location used during the Covid-19 pandemic. This is under the Letter (SE) Number 4 of 2020 that emphasized the learning process from home through online learning.

Furthermore, despite there are many online platforms on the internet for virtual learning activities, the Zoom platform is still the most popular in the virtual learning process $(38 \%)$, followed by Google meet platform (32\%). Whatsapp platform is quite popular in communication, however, Whatsapp's limitations in only text content and group communication make this platform is not recommended in virtual learning activities. A similar finding was also found by Sayem et al. [9]. According to the authors, the use of the Zoom platform as virtual learning resulted in higher satisfaction for engineering students.

\subsection{Motivation of Respondents}

Table 3 displays the results of the questionnaire distribution of students' motivation towards the effectiveness of virtual learning implementation which is divided into three variables as follows: pleasant, enthusiasm, and challenge.
Table 3. Motivation of respondents

\begin{tabular}{|c|c|c|}
\hline Characteristics & Frequency & $\begin{array}{c}\text { Percentage } \\
(\%)\end{array}$ \\
\hline \multicolumn{3}{|c|}{$\begin{array}{l}\text { Virtual learning is pleasant } \\
\text { or fun }\end{array}$} \\
\hline Agree (4-5) & 6 & 12 \\
\hline Quite agree (3) & 21 & 42 \\
\hline Disagree (1-2) & 23 & 46 \\
\hline \multicolumn{3}{|c|}{ Enthusiasm to attend virtual learning } \\
\hline Agree (4-5) & 17 & 34 \\
\hline Quite agree (3) & 28 & 56 \\
\hline Disagree (1-2) & 5 & 10 \\
\hline \multicolumn{3}{|c|}{ Virtual learning provides a challenge } \\
\hline Agree (4-5) & 29 & 58 \\
\hline Quite agree (3) & 19 & 38 \\
\hline Disagree (1-2) & 2 & 4 \\
\hline
\end{tabular}

The results showed that the motivation for civil engineering students was quite good in the implementation of virtual learning. This is shown in the survey results which states that the enthusiasm of most students is quite high $(56 \%)$ in attending virtual learning classes, even around $34 \%$ of students have a high motivation towards virtual learning implementation. Besides, more than half of respondents $(58 \%)$ stated that virtual learning turned out to be a challenge for civil engineering students, while $38 \%$ of respondents thought that virtual learning was quite challenging. A similar finding was also found by several researchers $[10,11]$. They found that students demonstrate a higher motivation when the course content interests them and a high interest in digital learning. However, although civil engineering students have a high enthusiasm, the implementation of virtual learning particularly for basic engineering and structure subjects in the civil engineering discipline, turned out to be less pleasant (42\%), even most respondents said that it was not fun $(46 \%)$.

\subsection{Perception towards the Level of Understanding}

The perception of civil engineering students toward the level of understanding of the course content during the virtual learning implementation are listed in Tabel 4.

Table 4. Perception towards level of understanding

\begin{tabular}{|c|c|c|}
\hline Characteristics & Frequency & $\begin{array}{c}\text { Percentage } \\
(\%)\end{array}$ \\
\hline $\begin{array}{l}\text { Virtual learning increases understanding of basic } \\
\text { engineering and structure lectures }\end{array}$ \\
\hline Agree (4-5) & 3 & 6 \\
\hline Quite agree (3) & 15 & 30 \\
\hline
\end{tabular}




\begin{tabular}{|c|c|c|}
\hline Disagree (1-2) & 32 & 64 \\
\hline \multicolumn{3}{|c|}{$\begin{array}{l}\text { Basic engineering and structure are easier to } \\
\text { understand using a virtual learning method }\end{array}$} \\
\hline Agree (4-5) & 4 & 8 \\
\hline Quite agree (3) & 15 & 30 \\
\hline Disagree (1-2) & 31 & 62 \\
\hline \multicolumn{3}{|c|}{$\begin{array}{l}\text { Virtual learning provides sufficient time for } \\
\text { exercises }\end{array}$} \\
\hline Agree (4-5) & 2 & 4 \\
\hline Quite agree (3) & 16 & 32 \\
\hline Disagree (1-2) & 32 & 64 \\
\hline
\end{tabular}

The survey results showed that most civil engineering students stated that the implementation of virtual learning was not able to increase the level of understanding of students in understanding the course material provided. This can be seen in the first results of the survey which states that more than half of students $(64 \%)$ think that the application of virtual learning is not able to increase the level of understanding for basic engineering and structure subjects in the civil engineering discipline. Also, the second survey results show that most of the students $(62 \%)$ also stated that the use of virtual learning did not facilitate students in understanding the material provided. According to most students (64\%), this is due to the lack of exercises that are given directly during virtual learning implementation. Also, students do not get hands-on experience in front of the class when working on assignments and exercises provided.

\subsection{Perception of Interaction}

Two interactions that occur in conventional teaching and learning processes, namely interaction between lecturers and students and interactions between students themselves. Table 5 explains the survey results related to the students' perceptions of these interactions in the teaching and learning process using virtual learning during the COVID-19 pandemic.

Table 5. Perception of interaction

\begin{tabular}{|c|c|c|}
\hline Characteristics & Frequency & $\begin{array}{l}\text { Percentage } \\
(\%)\end{array}$ \\
\hline \multicolumn{3}{|c|}{$\begin{array}{l}\text { Virtual learning provides easier interaction between } \\
\text { lecturers and students }\end{array}$} \\
\hline Agree (4-5) & 7 & 14 \\
\hline Quite agree (3) & 23 & 46 \\
\hline Disagree (1-2) & 20 & 40 \\
\hline \multicolumn{3}{|c|}{$\begin{array}{l}\text { Virtual learning provides easier interaction between } \\
\text { students }\end{array}$} \\
\hline Agree (4-5) & 5 & 10 \\
\hline Quite agree (3) & 20 & 40 \\
\hline
\end{tabular}

\begin{tabular}{|c|c|c|}
\hline Disagree (1-2) & 25 & 50 \\
\hline \multicolumn{3}{|c|}{$\begin{array}{l}\text { Miscommunication between lecturers and students is } \\
\text { more common in virtual learning }\end{array}$} \\
\hline Agree (4-5) & 31 & 62 \\
\hline Quite agree (3) & 15 & 30 \\
\hline Disagree (1-2) & 4 & 8 \\
\hline \multicolumn{3}{|c|}{$\begin{array}{l}\text { Miscommunication between students is more } \\
\text { common in virtual learning }\end{array}$} \\
\hline Agree (4-5) & 38 & 76 \\
\hline Quite agree (3) & 9 & 18 \\
\hline Disagree (1-2) & 4 & 8 \\
\hline
\end{tabular}

Most students stated that the application of virtual learning makes the interactions that occur during the teaching and learning process become more difficult compare to that conventional learning method. This is shown in the survey results which states that the learning process through virtual learning does not provide a significant interaction between lecturers and students $(46 \%) .40 \%$ of students stated that the interaction between lecturers and students did not go well and easily as planned during the virtual learning process. In terms of student interaction, half of the civil engineering students (50\%) stated that the virtual learning implementation complicates their interaction between themselves during the virtual learning process. This interaction issue has caused miscommunication between lecturers and students $(62 \%)$. Furthermore, the majority of civil engineering students $(76 \%)$ agree that miscommunication between students themselves is more common in the implementation of virtual learning. According to Mersham [12], communication between lecturers and learners does not optimally occur in the e-learning process in the same way as they do in conventional or face-to-face learning environments.

\subsection{Perception of Virtual Learning Problems Encountered}

Virtual learning has two inseparable sides. Besides having a positive side, virtual learning also has negative sides or problems that may arise with the implementation of virtual learning. Table 6 displays the possible problems that arise due to the implementation of virtual learning during the COVID-19 pandemic which categorized as follows: flexibility, internet cost, internet access, and facilities.

In terms of internet costs, most civil engineering students agree that virtual learning requires high costs compared to conventional or face-to-face methods. The survey results showed that almost all students stated that virtual learning requires high cost $(84 \%)$ and requires a more expensive cost compared to the face-to-face learning 
model $(60 \%)$. The results of this study are also supported by the condition of the students who have difficulties with the cost factor for accessing virtual learning during lecturing, where almost all students $(90 \%)$ stated the cost difficulty to carry out the virtual learning process.

Table 6. Perception of virtual learning problems encountered

\begin{tabular}{|c|c|c|}
\hline Characteristics & Frequency & $\begin{array}{l}\text { Percentage } \\
(\%)\end{array}$ \\
\hline \multicolumn{3}{|c|}{$\begin{array}{l}\text { The cost of internet access in virtual learning is } \\
\text { expensive }\end{array}$} \\
\hline Agree (4-5) & 42 & 84 \\
\hline Quite agree (3) & 7 & 14 \\
\hline Disagree (1-2) & 1 & 2 \\
\hline \multicolumn{3}{|c|}{$\begin{array}{l}\text { Virtual learning requires a higher cost than the face- } \\
\text { to-face method }\end{array}$} \\
\hline Agree (4-5) & 30 & 60 \\
\hline Quite agree (3) & 15 & 30 \\
\hline Disagree (1-2) & 5 & 10 \\
\hline
\end{tabular}

\section{Students difficulty with cost in virtual learning lectures}

\begin{tabular}{|l|c|c|}
\hline Agree (4-5) & 23 & 46 \\
\hline Quite agree (3) & 22 & 44 \\
\hline Disagree (1-2) & 5 & 10 \\
\hline
\end{tabular}

\section{No interruptions in internet access during the online} lecture

\begin{tabular}{|l|c|c|}
\hline Agree (4-5) & 4 & 8 \\
\hline Quite agree (3) & 16 & 32 \\
\hline Disagree (1-2) & 30 & 60 \\
\hline
\end{tabular}

\section{Virtual learning support facilities meet the} requirements

\begin{tabular}{|c|c|c|}
\hline Agree (4-5) & 7 & 14 \\
\hline Quite agree (3) & 24 & 48 \\
\hline Disagree (1-2) & 19 & 38 \\
\hline \multicolumn{3}{|c|}{ Virtual learning support facilities need to be improved } \\
\hline Agree (4-5) & 45 & 90 \\
\hline Quite agree (3) & 4 & 8 \\
\hline Disagree (1-2) & 1 & 2 \\
\hline \multicolumn{3}{|c|}{ Virtual learning time is flexible } \\
\hline Agree (4-5) & 16 & 32 \\
\hline Quite agree (3) & 22 & 44 \\
\hline Disagree (1-2) & 12 & 24 \\
\hline
\end{tabular}

In terms of facility and internet access, Although almost all civil engineering students acknowledge that internet access is a major problem and often experience problems when implementing virtual learning (92\%), half of the students state that virtual learning support facilities have met the requirements. However, the problem of internet access should not be ignored because some students (38\%) stated that internet access was not feasible and did not meet the requirements. In general, almost all students agreed (98\%) that internet facilities in supporting virtual learning need to be improved to meet eligibility during the virtual learning process. A similar finding was also found by Eldeeb [13]. According to the author, the technical problem is the main issue of the e-learning process which requires addressing the internet access and broadband width.

Furthermore, in terms of flexibility, $76 \%$ of civil engineering students are agreed that the time for virtual learning implementation is flexible. This is because the virtual learning process can be carried out anywhere and at any time, regardless of place and time. This makes it easier for students to carry out virtual learning processes from home or other places during the lock-down policy and learning from home in their learning institutions.

\section{CONCLUSIONS}

Based on the results of the discussion, the perception of civil engineering students on the effectiveness of the virtual learning implementation during the COVID-19 pandemic can be concluded as follows:

a) The implementation of virtual learning was not quite effective based on civil engineering student's perception, particularly in basic engineering and structure subject in the civil engineering discipline.

b) Despite the civil engineering students were quite an enthusiasm due to its technical challenge and time flexibility, there are some major problems in virtual learning implementation.

c) There five major problems in the implementation of virtual learning, which are: 1) the level of understanding, 2) the social interaction during virtual learning processes include the interaction between lecturers and students as well as the interaction between the students themselves, 3 ) the internet cost, and 4) internet access and facilities.

\section{ACKNOWLEDGMENT}

The authors would like to thanks Univesitas Negeri Surabaya for the support and funding through the 2020 Policy Research Funding Scheme of Engineering Faculty.

\section{REFERENCES}

[1] J. Crawford, K. Butler-Henderson, J. Rudolph, B. Malkawi, M. Glowatz, R. Burton, et al., "COVID19: 20 countries' higher education intra-period digital pedagogy responses," Journal of Applied Learning \& Teaching, vol. 3, pp. 1-20, 2020. 
[2] M. B. N. Wajdi, I. Kuswandi, U. A. Faruq, Zulhijra, Khairudin, and Khoiriyah, "Education policy overcome Coronavirus, a study of Indonesians," Edutec, vol. 3, pp. 96-106, 2020.

[3] W. Zhang, Y. Wang, L. Yang, and C. Wang, "Suspending classes without stopping learning: China's education emergency management policy in the Covid-19 outbreak," Journal of Risk and Financial Management, vol. 13, pp. 1-6, 2020.

[4] S. D. Johnson, S. R. Aragon, N. Shaik, and N. Palma-Rivas, "Comparative analysis of learner satisfaction and learning outcomes in online and face-to-face learning environments," Journal of Interactive Learning Research vol. 11, pp. 29-49, 2000 .

[5] M. A. Shields, "Technological change, virtual learning, and higher education: Prospects, problems, potentials," in Social Dimensions of Information Technology: Issues for the New Millennium, G. D. Garson, Ed., ed USA: Idea Group Publishing, 2000, pp. 160-176.

[6] T. Daradoumis and F. Xhafa, "Problems and opportunities of learning together in a virtual learning environment," in Computer-Supported Collaborative Learning in Higher Education, T. S. Roberts, Ed., ed USA: Idea Group Publishing, 2004, pp. 218-233.

[7] A. Joshi, S. Kale, S. Chandel, and D. K. Pal, "Likert Scale: Explored and explained," British Journal of Applied Science \& Technology, vol. 7, pp. 396-403, 2015.

[8] A. K. Bhalerao, "Application and performance of Google Forms for online data collection and analysis: A case of North Eastern Region of India," Indian Journal of Extension Education, vol. 51, pp. 49-53, 2015.

[9] A. S. M. Sayem, B. Taylor, M. McClanachan, and U. Mumtahina, "Effective use of zoom technology and instructional videos to improve engagement and success of distance students in engineering," presented at the 28th Annual Conference of the Australasian Association for Engineering Education (AAEE 2017), Sydney, Australia, 2017.

[10] K. L. Smart and J. J. Cappel, "Students perception of online learning: A comparative study," Journal of Information Technology Education, vol. 5, 2006.

[11] R. Daud, Z. A. Jalil, and M. N. F. M. Gunawan, "Community college students perception towards digital learning in Malaysia " Procedia Social and Behavioral Sciences, vol. 195, pp. 1798-1802, 2015.

[12] G. Mersham, "Reflection on e-learning from a communication perspective," Journal of Distance Learning, vol. 13, pp. 51-70, 2009.

[13] R. A. Eldeeb, "Students' perception to e-learning," IOSR Journal of Research \& Method in Education, vol. 4, pp. 33-36, 2014. 